KAY, D. (1954). J. gen. Microbiol. 11, 45-51.

\title{
The Deoxyribonuclease of Typhoid Bacilli and its Effect on Typhoid Bacteriophage Nucleic Acid
}

\author{
BY D. KAY \\ Virus Research Unit, British Empire Cancer Campaign, Sir William \\ Dunn School of Pathology, University of Oxford
}

SUMMARY: Deoxyribonuclease (DNase) was found in extracts of a strain of Salmonella typhi. Its action on herring sperm deoxyribonucleic acid (DNA) is catalysed by magnesium ions. Calcium ions, although inactive alone, increase the magnesium-catalysed activity of the enzyme. A highly polymerized specimen of phage DNA was prepared by treatment of the purified phage with strong urea solution to dissolve the protein coat. This nucleic acid is degraded by the typhoid DNase in the presence of magnesium. As with herring sperm DNA, calcium is inactive alone but increases the action of magnesium. Calcium is required for multiplication of the phage in the host bacterium, but the hypothesis that the calcium is required to catalyse the breakdown of phage DNA by bacterial DNase was not upheld.

Interest in the relation between deoxyribonuclease (DNase) and bacteriophage derives from their common requirement for bivalent metals and the high content of deoxyribonucleic acid (DNA) in bacteriophage. Mammalian DNase is catalysed by magnesium ions (McCarty, 1946) and certain phages, notably coli phage T5 (Adams, 1949; Kay, 1952) and a typhoid phage (Fildes, Kay \& Joklik, 1952) require bivalent metals for their multiplication. Calcium ions are highly specific for the typhoid phage and are the most active of a small group of metal ions for phage T5. In the typhoid phage system the absence of calcium causes the majority of the phage particles in a mixture of phage and bacteria to be inactivated. This inactivation is a consequence of adsorption to the cells and does not take place when the phage alone is suspended in calcium-free medium.

If the findings of Hershey \& Chase (1952) with coli phage T2 are applicable to the typhoid phage, then the next stage after adsorption has taken place is the transfer of nucleic acid from the phage to the bacterium, the protein envelope of the phage taking no further part in the multiplication of the virus. The nucleic acid of the parent phage is not all transferred to the progeny, the amount varying from 23 to $62 \%$ in different experiments (French, Graham, Lesley \& van Rooyen, 1952). Hershey (1953) reported that only $40 \%$ of the parental phosphorus was found in the progeny. The transfer of a small but specific part of the parent phage nucleic acid to the progeny has not been ruled out but it has been suggested by Kozloff (1952) in the case of coliphage T6 that most of the parent virus material found in the progeny was due to the use of breakdown products of the parent virus for the synthesis of new virus nucleoprotein. This suggests, although direct evidence is lacking, that the breakdown of phage DNA might be a necessary stage in the multiplication of 
the virus. If this were so then DNase would probably take part in the degradation. The phages which require calcium for their multiplication may possess nucleic acids of a different type from those of other phages in that the action of DNase is catalysed by calcium instead of magnesium. If this were so then the action of calcium could be explained as that of a catalyst in the breakdown of the phage nucleic acid into polynucleotides prior to their taking part in the production of new phage particles. In the absence of calcium the phage DNA could not be broken down and might even be prevented by the large size of its molecules from entering the cell. From this hypothesis it was expected that the host bacteria would contain DNase and that its action on phage DNA would be different from its action on a non-viral DNA. The work to be described in this paper comprises $(a)$ the examination of a strain of Salmonella typhi for DNase, (b) the preparation of typhoid phage DNA, and (c) the study of the effect of calcium and magnesium on the interaction of the two.

\section{MATERIALS AND METHODS}

Bacteria. The strain of Salmonella typhi described by Kay \& Fildes (1950) was used. This is a 'rough' mutant derived from NCTC 3390. Cultures were grown in a glucose-ammonia medium as described by Kay (1952).

Bacteriophage. The phage was the same strain as that used by Kay \& Fildes (1950). It was prepared and purified by the same technique as that described for coli phage T5 (Kay, 1952). Dr A. Felix has examined this phage and states that it is indistinguishable from his standard $O$ phages No. 1, 2 and 3.

Deoxypentose nucleic acid. This was prepared from herring sperm by the method of Daly, Allfrey \& Mirsky (1950).

Estimation of deoxyribonuclease activity. The spectrophotometric method of Kunitz (1950) was used except that acetate buffer was replaced by phosphate buffer at $\mathrm{pH} 7 \cdot 6$. Undegraded nucleic acid was precipitated from the samples by the addition of $0.25 \mathrm{~N}-\mathrm{H}_{2} \mathrm{SO}_{4}$ and the material rendered acid-soluble by enzyme action was estimated by its absorption at $260 \mathrm{~m} \mu$. Measurements were made in a Hilger 'Uvispek' absorptiometer.

\section{RESULTS}

\section{Deoxyribonuclease in typhoid bacilli}

Extracellular DNase production by this organism was tested for by spreading the bacteria on the surface of nutrient agar impregnated with $0.3 \%(w / v)$ of DNA and incubating overnight at $37^{\circ}$. When the plates were flooded with a solution of mercuric chloride in $\mathrm{HCl}$, a reagent which precipitates the undegraded DNA in the agar causing a turbidity to appear, it was seen that the bacteria did not produce a detectable extracellular enzyme as the DNA was precipitated right up to the colonies. A control plate spread with a strain of Bacillus subtilis known to produce DNase showed clear areas round the colonies.

Intracellular DNase was tested for by disintegrating the cells, incubating 
the product with a solution of DNA and measuring the release of acid soluble degradation products of the nucleic acid. The cells from an overnight culture in $100 \mathrm{ml}$. chemically-defined medium were harvested by centrifugation, suspended in $10 \mathrm{ml}$. of $0.01 \mathrm{M}$-phosphate buffer at $\mathrm{pH} 7 \cdot 6$, and crushed by vibration with 'ballotini' beads in a Mickle shaker. After 15 min. shaking the beads were removed by decantation and the supernatant containing both soluble and insoluble cell material was tested as follows. To $5 \mathrm{ml}$. of a solution of DNA in water $(1 \mathrm{mg} . / \mathrm{ml}$.) was added $1 \mathrm{ml} .0 .1 \mathrm{M}$-magnesium sulphate and $0 \cdot 1 \mathrm{ml}$. crushed cell suspension in buffer $(\mathrm{pH} 7 \cdot 6)$, the final concentration of which was $0.00016 \mathrm{M}$. The concentration of the crushed cell material was $200 \mu \mathrm{g} . / \mathrm{ml}$. The mixture was incubated at $37^{\circ}$. Samples $(1 \mathrm{ml}$.) were withdrawn at intervals and added to $4 \mathrm{ml}$. ice-cold $0.25 \mathrm{~N}$-sulphuric acid. After standing for $30 \mathrm{~min}$. the precipitates were removed by centrifugation and the ultraviolet absorption of the supernatants at $260 \mathrm{~m} \mu$. was measured. A suspension of whole cells of the same concentration as that used to prepare the crushed cells was also tested and controls of DNA alone and crushed cells alone were included. The results are shown in Fig. 1. DNA alone was not degraded but the whole cells had a slight effect. Presumably this activity was too small to show in the impregnated agar test. The crushed cells, on the other hand, had a marked effect which indicated that the bacteria possessed an intracellular DNase.

It was now of interest to determine whether the enzyme was in solution or attached to the bacterial debris. The crushed cells were centrifuged at $4000 \mathrm{~g}$ for $10 \mathrm{~min}$. and the opalescent supernatant was decanted. The sediment was taken up in phosphate buffer and it and the supernatant were tested for DNase activity by the method described above. The results which are given in Fig. 2 show that the activity of the supernatant is almost equal to that of the crushed cells, and that the enzyme is either in solution or present in the form of very small particles unsedimentable at $4000 \mathrm{~g}$. This supernatant was used in subsequent experiments and is referred to as 'typhoid DNase'.

The ordinate in Figs. 1 and 2 is the absorption at $260 \mathrm{~m} \mu$. of the acid soluble degradation products of the DNA. The initial reading of about 0.5 is due to the presence in the sample of DNA of a small amount of acid-soluble material, probably produced by the partial degradation of the DNA during its preparation.

\section{The effect of magnesium and calcium on typhoid deoxyribonuclease}

Calcium and magnesium were tested as activators of typhoid DNase by addition of solutions of the chloride and sulphate respectively to mixtures of the enzyme preparation and DNA. Samples were taken from the incubated mixture and the amount of degradation measured as in previous experiments. Calcium was found to have no effect, the enzyme remaining inactive at concentrations of this element between 0.0005 and $0.01 \mathrm{M}$. Magnesium, on the other hand, showed an activity increasing with concentration (Fig. 3). However, when magnesium and calcium were tested together it was found that the calcium increased the activity of the magnesium. A typical example of this 
effect is given in Fig. 4 in which the addition of $0.003 \mathrm{M}$-calcium to $0.003 \mathrm{M}$ magnesium increased the rate of degradation of DNA by $75 \%$, whereas calcium alone had no effect at all.

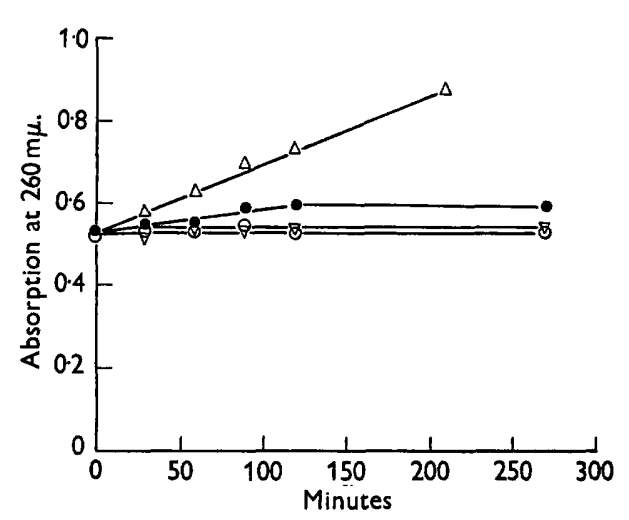

Fig. 1

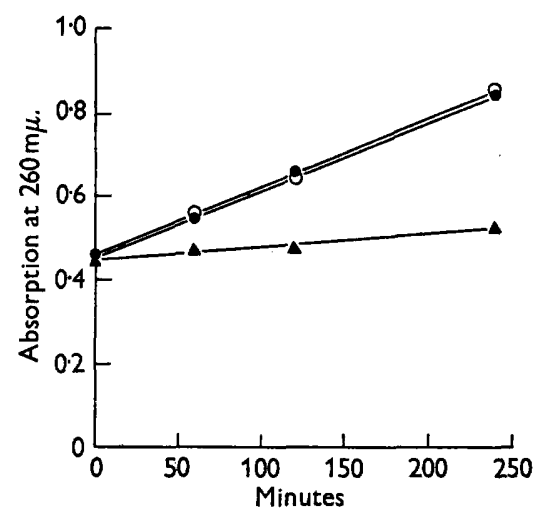

Fig. 2

Fig. 1. The action of whole and crushed Salmonella typhi on DNA (800 $\mu \mathrm{g} . / \mathrm{ml}$.) at pH 7.6 and $37^{\circ}$. The cell concentration whole and crushed was $200 \mu \mathrm{g} . / \mathrm{ml}$. $\bigcirc-O$, DNA alone; - - , whole cells + DNA; $\triangle-\triangle$, crushed cells + DNA; $\nabla-\nabla$, crushed cells alone.

Fig. 2. The action of the supernatant and sediment from centrifuged crushed Sal. typhi on DNA $\left(800 \mu \mathrm{g} . / \mathrm{ml}\right.$.) at $\mathrm{pH} 7 \cdot 6$ and $37^{\circ}$. The crushed cell concentration was $200 \mu \mathrm{g} . / \mathrm{ml}$. $\mathrm{O}-\mathrm{O}$, crushed cells + DNA; - - , supernatant from crushed cells +DNA; $\mathbf{A}-\mathbf{\Delta}$, sediment from crushed cells + DNA.

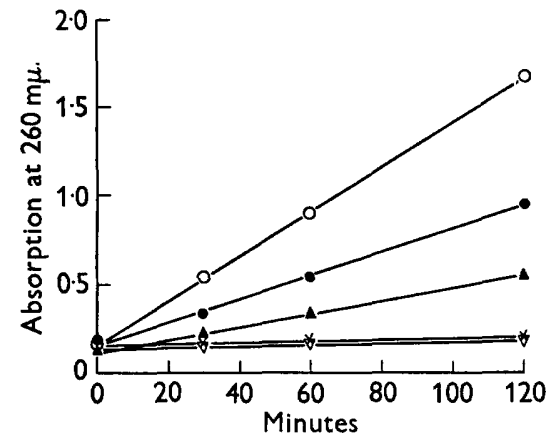

Fig. 3

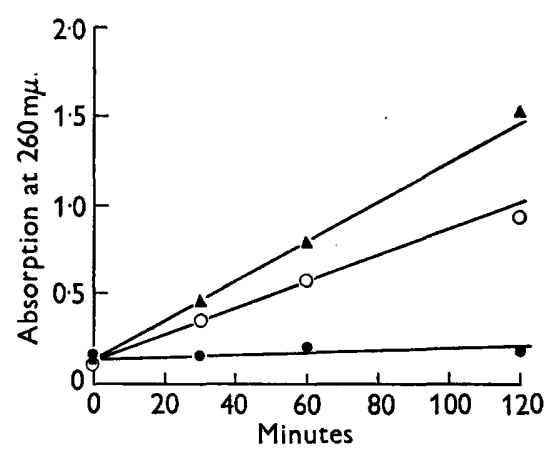

Fig. 4

Fig. 3. The effect of magnesium and calcium on the action of typhoid DNase on DNA $\left(800 \mu \mathrm{g} . / \mathrm{ml}\right.$.) at $\mathrm{pH} 7 \cdot 6$ and $37^{\circ}$. O-, $0.016 \mathrm{M}$-magnesium; -0, 0.0033 M-magnesium; $\Delta-\Delta, 0.0008$ m-magnesium; $\nabla-\nabla$, no magnesium; $x \longrightarrow \times, 0.01$ m-calcium.

Fig. 4. The effect of calcium on the action of typhoid DNase on DNA (800 $\mu \mathrm{g} . / \mathrm{ml}$.) activated by magnesium at $\mathrm{pH} 7 \cdot 6$ and $37^{\circ}$. - $-0.0033 \mathrm{M}$-calcium; $0-0,0.0033 \mathrm{M}-\mathrm{mag}$ nesium; $\Delta-\Delta, 0.0033 \mathrm{M}$-calcium +0.0033 $\mathrm{M}$-magnesium.

\section{Typhoid deoxyribonuclease and typhoid phage deoxypentose nucleic acid}

DNase is unable to attack phage DNA while the phage is intact (Hershey $\&$ Chase, 1952). This is probably due to the fact that the nucleic acid is enclosed by a protein coat impermeable to the enzyme. Therefore in order to study the 
effect of DNase on phage DNA the protein coat must be removed and the DNA exposed. As it is necessary to prepare the DNA in as highly polymerized a form as possible the procedure used must be a mild one. Cohen (1947) described the use of strong urea solution to liberate the nucleic acid of coliphages T2 and T4. This method, in modified form, was tried on the typhoid phage. Two litres of lysate containing $3 \times 10^{10}$ phage particles $/ \mathrm{ml}$. were prepared and the phage separated by differential centrifugation. The phage was resuspended in 0.01 M-phosphate buffer and again sedimented at high speed. The sediment was taken up in a mixture of $5 \mathrm{ml} .50 \%(\mathrm{w} / \mathrm{v})$ solution of urea in water and $1 \mathrm{ml}$. $0 \cdot 1 \mathrm{M}$-glycine $+\mathrm{NaOH}$ buffer $(\mathrm{pH} \mathrm{9 \cdot 6})$. The mixture was stirred vigorously and a clear viscous solution was formed. Protein was removed by repeated shaking with chloroform + amyl alcohol mixture and the nucleic acid precipitated by pouring into $100 \mathrm{ml} .95 \%$ ethanol. The fibrous

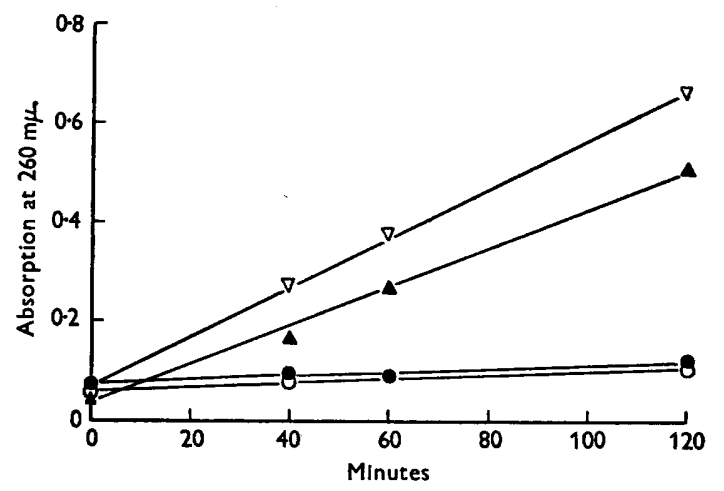

Fig. 5. The effect of calcium and magnesium on the breakdown of phage DNA $(800 \mu \mathrm{g} . / \mathrm{ml}$.) by typhoid DNase at $\mathrm{pH} 7.6$ and $37^{\circ}$. - $0,0.0033 \mathrm{~m}$-calcium; $\triangle-\Delta, 0.0033 \mathrm{~m}-$ magnesium; $\nabla-\nabla, 0.0033 \mathrm{M}$-calcium + 0.0033 $\mathrm{m}$-magnesium; $O-O$, no addition.

precipitate was washed in $95 \%$ ethanol and dried with absolute ethanol and ether. The product (6.6 mg.) when dissolved in water $(1 \mathrm{mg} . / \mathrm{ml}$.) gave a weak gel. Its ultraviolet absorption spectrum showed a peak at $260 \mathrm{~m} \mu$. typical of nucleic acid, and paper chromatography in isopropanol/ $\mathrm{HCl}$ of a formic acid hydrolysate showed the presence of adenine, guanine, thymine and 'cytosine'. It is not known whether the spot visible in the cytosine position was cytosine or 5-hydroxymethylcytosine, which is present in the T-even coli phages, as both these substances migrate to the same place in this solvent (Wyatt \& Cohen, 1952). No uracil was found; the purines and pyrimidines were those typical of deoxyribonucleic acid.

The effect of typhoid DNase on phage DNA was examined in the same manner as on the herring sperm DNA, except that the volume of the reactants was reduced to conserve material. The total volume of the mixed reactants was $1.0 \mathrm{ml}$. and samples of $0.1 \mathrm{ml}$. were taken. The ultraviolet absorption of the acid soluble material was measured in the micro-cells of the Uvispek instrument. The results of an experiment to test the effect of calcium and magnesium are given in Fig. 5. The degradation of phage DNA was catalysed 
by magnesium but not by calcium, and as in the case of herring sperm DNA calcium increased the activation caused by magnesium, although to a lesser extent.

\section{DISCUSSION}

Several species of bacteria which produce DNase have been described, for example various clostridia and streptococci, but in all cases the enzyme has been secreted into the medium. The particular strain of Salmonella typhi used in the present experiments produced very little extracellular enzyme although one is present, as expected, in the cell contents. The action of this enzyme, in the form of a crude extract, on herring sperm DNA is catalysed by magnesium ions as is the action of DNase of mammalian origin (McCarty, 1946). Calcium is not an activator but it does increase the action of magnesium. The breakdown of DNA derived from bacteriophage is also catalysed by magnesium. Again calcium, which is inactive alone, increases the rate of the magnesium catalysed reaction. This effect could be due to the displacement of magnesium by calcium from combination with sites which are not essential for enzymic action. These sites may exist on protein impurities in the crude enzyme preparation. The released magnesium could then combine with the substrateenzyme complex in such a way as to cause activation.

The experiments described in this paper do not disclose any property of the nucleic acid which could account for the peculiar calcium requirement of the phage. On the contrary, the remarkably similar reactions of phage DNA and herring sperm DNA with DNase show that these two preparations, although from widely different sources, possess some similarity of structure.

My thanks are due to Sir Paul Fildes, F.R.S., for his interest in the work and his valuable criticism, and to the Medical Research Council for a personal grant.

\section{REFERENCES}

Adams, M. H. (1949). The calcium requirement of coliphage T5. J. Immunol. 62, 505.

CoHen, S. S. (1947). The synthesis of bacterial viruses in infected cells. Cold Spr. Harb. Symp. quant. Biol. 12, 35.

Daly, M. M., Allfrey, V. G. \& Mirsky, A. E. (1950). Purine and pyrimidine contents of some deoxypentose nucleic acids. J. gen. Physiol. 33, 497.

Fildes, P., KAY, D. \& Jokur, W. K. (1952). Divalent metals in phage production. In The Nature of Virus Multiplication. Symp. Soc. gen. Microbiol. 2, 194.

French, R. C., Graham, A. F., Lesley, S. M. \& van Rooyen, C. E. (1952). The contribution of phosphorus from $\mathrm{T} 2 r^{+}$bacteriophage to progeny. J. Bact. $64,597$.

Hershey, A. D. (1953). Nucleic acid economy in bacteria infected with bacteriophage T2. J. gen. Physiol. 37, 1.

Hershey, A. D. \& Chase, M. (1952). Independent functions of viral protein and nucleic acid in growth of bacteriophage. J. gen. Physiol. 36, 39.

KAy, D. (1952). The effect of divalent metals on the multiplication of coli bacteriophage T5st. Brit. J. exp. Path. 33, 228.

KAY, D. \& Fildes, P. (1950). The calcium requirement of a typhoid bacteriophage. Brit. J. exp. Path. 31, 338. 
KozLoff, L. M. (1952). Biochemical studies of virus reproduction. J. biol. Chem. 194, 95.

Kunitz, M. (1950). Crystalline desoxyribonuclease. J. gen. Physiol. 33, 363.

McCarty, M. (1946). Purification and properties of desoxyribonuclease isolated from beef pancreas. J. gen. Physiol. 29, 123.

Wyatt, G. R. \& CohEn, S. S. (1952). A new pyrimidine base from bacteriophage nucleic acids. Nature, Lond. 170, 1072.

(Received 12 January 1954) 